Pamiętnik Literacki 2019, 1, s. 140-148

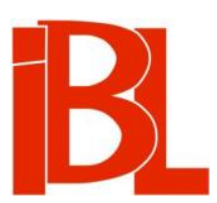

\title{
Recepcja literacka - jak może być rozumiana we współczesnym literaturoznawstwie?
}

Anna Jarmuszkiewicz 
Pamiętnik Literacki CX, 2019, z. 1, PL ISSN 0031-0514

DOI: $10.18318 / \mathrm{pl} .2019 .1 .8$

ANNA JARMUSZKIEWICZ Uniwersytet Jagielloński, Kraków

\section{RECEPCJA LITERACKA - JAK MOŻE BYĆ ROZUMIANA WE WSPÓŁCZESNYM LITERATUROZNAWSTWIE?}

Pytanie o znaczenie i funkcje pojęcia recepcji (w tym także tej znajdujaccej odbicie w sztuce słowa, przez Michała Głowińskiego nazywanej „dialogiem symetrycznym” ${ }^{1}$ ) utworu literackiego pozostaje wciąż aktualne i otwarte, nasuwając kolejne problemy. Badania nad tym zagadnieniem w latach siedemdziesiątych XX wieku stały się forpocztą literaturoznawstwa - miały stanowić remedium na kryzys legitymizacji tej dziedziny. Stworzyły niejako nowy jej paradygmat, w dużym stopniu przenoszac środek ciężkości procesu interpretacyjnego $\mathrm{z}$ intencjonalności autora i formy tekstu na swobodę interpretacyjną odbiorcy. W związku z tym swoją ostrość straciło kategoryczne i obrazowe stwierdzenie Wystana H. Audena, który uważał, że „Jako czytelnicy prawie wszyscy przypominamy trochę owych uliczników, którzy domalowują wąsy pannom na afiszach" 2 . W nowej sytuacji tekst znalazł się w pewnym sensie w rękach osoby przeprowadzającej jego lekturę i został umieszczony w tej perspektywie interpretacyjnej. Owa zmiana jednak (na szczęście?) nie rozwiała ostatecznie wątpliwości co do pozycji zajmowanych przez autora, tekst i odbiorcę oraz co do rodzaju relacji łączących ich w komunikacji literackiej.

Pytanie, na które docelowo chcę odpowiedzieć w niniejszym artykule: „Jak można dziś rozumieć pojęcie recepcji literackiej?”, poprzedzę dwoma innymi, pomocniczymi: czy badania nad recepcją sa jeszcze użyteczne dla współczesnego literaturoznawstwa? czy nie dzieje się jednak może tak, że - ujmując rzecz nieco kolokwialnie - „król jest nagi”, że nie ma już nic do odkrycia i omawiane studia osiagnęły kres poznawczy? Kariera odbioru i odbiorcy miała przecież swój wymiar paradoksalny - prymat czytelnika w interpretacji sensu utworu implikuje liczne niejasności, które rodza problemy ${ }^{3}$, podobnie jak wcześniej czyniły to konflikty o prymat intencji autora i autorytetu tekstu. Jak pisze Antoine Compagnon:

Długo ignorowany przez filologię, a potem przez New Criticism, formalizm i strukturalizm, trzymany na dystans jak natręt w imię „iluzji uczuciowej”, czytelnik, powracając na scenę literacką obok autora i tekstu (lub pomiędzy nich, przeciw autorowi i tekstowi), przełamał ich binarną opozycję, zniósł

1 Pojęcie wprowadzone przez M. Głowińskiego w artykule Komunikacja literacka jako sfera napięć (w zb.: Style odbioru. Szkice o komunikacji literackiej. Kraków 1977, s. 12) i określone jako sytuacja, w której „odpowiedzią na daną wypowiedź literacka jest inna wypowiedź literacka”.

2 W. H. Au d e n, O czytaniu. W: Ręka farbiarza i inne eseje. Wybór M. Sprus ińs ki, J. Zi elińs ki. Wstęp J. Zielińs ki. Warszawa 1988, s. 16 (przeł. H. Krzeczkows ki).

3 Chodzi tu o problemy takie jak nadmiar subiektywizacji, łamiący zasady, według których można ocenić odpowiedniość i stosowność interpretacji. 
ich alternatywę, która stała się jałowa. [...] Tyle że, znalazłszy się już na placu boju, teraz z kolei walczący w obronie czytelnika chcieli wykluczyć wszystkich swych konkurentów. Autor i tekst - a w końcu i sam czytelnik - okazali się niezdolni sprostać wymaganiom teoretyków recepcji ${ }^{4}$.

Na drugie z owych pytań pomocniczych (mające charakter retoryczny) odpowiem, nie zwlekając: mimo wszystkich wspomnianych trudności kwestia czytelnika i recepcji nadal jest w badaniach nad sztuką słowa oczywiście ważna i nieuchronnie powraca (jak pisał Stanley Fish: „Większość sporów literackich bierze się nie z różnic odbioru, lecz z tego, że odbiór jest różnie odbierany”5). W pierwszej kolejności muszę wskazać na aspekt pragmatyczny: w pracy poświęconej problemom recepcji literackiej nie sposób zaprzeczyć jej istotności, skoro zagadnienie to się podejmuje i poddaje rozważaniom. Ponadto należy podkreślić, że - czy tego chcemy, czy nie pytanie o odbiór i o czytelnika zawsze pozostanie podstawowe dla literaturoznawstwa, choćby temat ów chwilowo nie wysuwał się na główny plan zainteresowań naukowych. Recepcja literacka nieodmiennie znajduje się więc w kręgu kwestii fundamentalnych dla omawianej dyscypliny. Dzieje się tak $z$ wielu różnych powodów, które mam nadzieję zasygnalizować w niniejszym szkicu.

Rozbudowane w latach sześćdziesiątych i siedemdziesiątych XX wieku badania nad recepcją obecnie uznawane są za ciekawe bardziej jako swego rodzaju fenomen historyczny niż jako element współczesnej praktyki interpretacyjnej. Czy ich dzieje się skończyły? Postaram się unaocznić, że oryginalnie wypracowane ujęcia estetyki recepcji mogą być nadal ważne i stanowić użyteczny drogowskaz dla literaturo- i kulturoznawstwa. Aby to uczynić, należy spojrzeć na studia nad tym zagadnieniem nie $z$ perspektywy ortodoksyjnej, ale myśląc o sztuce słowa w sposób otwarty na jej twórczy i szeroki aspekt. Jak pisze w tym kontekście Winfried Fluck, taką wspólną przestrzenią może być próba połączenia zadań estetyki recepcji, antropologii literackiej oraz Funktionsgeschichte, czyli badań nad zmieniającymi się funkcjami literatury ${ }^{6}$.

Studia nad estetyką recepcji uwypukliły społeczne funkcjonowanie literatury i sformułowały (piórem Wolfganga Isera) podstawowe pytanie: dlaczego ludzie czytaja, choć - z zasady - mają świadomość, że to, co czytają, jest tylko fikcja? Niewykluczone, iż dzieje się tak dlatego, że nie czyta się literatury dla sensu zawartego w utworze, dla obiektywnej wiedzy, lecz w zupełnie innym celu. Można zauważyć, że asymetryczna relacja, jaka nawiązuje się między czytelnikiem a tekstem (asymetria ta wynika m.in. $z$ braku utożsamienia tekstu i znaczenia) bywa dla tego pierwszego właśnie szansą na samodzielne i krytyczne myślenie. Myślenie takie rozumiem tutaj nie tyle jako profesjonalne podejście do utworu, jako „lekturę znawców" (by posłużyć się terminem sformułowanym przez Janusza Sławińskiego ${ }^{7}$ ),

4 A. C o m pagn o n, Demon teorii. Literatura a zdrowy rozsadek. Przeł. T. Stróży ń s ki. Gdańsk 2010, s. 145.

5 Cyt. za: A. Skrend o, Recepcja literatury: przedmiot, zakresy, cele badań. Komentarz do tytutu i postscriptum. W zb.: Sporne i bezsporne problemy wspótczesnej wiedzy o literaturze. Red. W. B olecki, R. Ny cz. Warszawa 2002, s. 89.

6 W. Fluck, Romance with America? Essays on Culture, Literature, and American Studies. Ed. L. Bi eger, J. Voelz. Heidelberg 2009, s. 366.

7 J. Sławińs ki, O dzisiejszych normach czytania (znawców). „Teksty” 1974, nr 3. 
ile jako efekt wrodzonej niestabilności tekstu, który jest każdorazowo aktualizowany przez dowolnego (bez względu na kompetencje) czytelnika (czyli również przez „nieznawce”). Inną kwestią wartą odnotowania wydaje się fakt, że ta „wolność myślenia" zawsze istnieje w pewnych ramach - wynikających $z$ kultury i funkcjonowania społecznego jednostki 8 .

Według Flucka klasyczna, Iserowska estetyka recepcji nie daje odpowiedzi na wiele pytań, dlatego w celu ich uzyskania warto wykorzystać projekt antropologii literatury. Posiłkując się pomysłami Isera, Fluck rozwija całkiem spójną koncepcję opartą na tym właśnie projekcie, w którym przeżycie estetyczne odbiorcy jest nieprzetłumaczalne, jednak $\mathrm{w}$ efekcie redeskrypcji produkuje on drugi tekst, który zapewnia wskazówki wykorzystywane podczas interpretacyjnego spotkania $\mathrm{z}$ tym pierwszym. Proces redeskrypcji w każdym przypadku będzie przebiegał inaczej, więc i odczytania tego samego tekstu każdorazowo okażą się różne. Jednak owe różnice mogą stać się pouczające i warto je badać, a co za tym idzie, obserwować najczęściej wykorzystywane wzory recepcji. W związku z tym, zauważa Fluck, „kulturowa historia literatury staje się historią różnych użyć tekstów w aktach recepcji. Historia literatury i historia recepcji są więc nierozłączne i nie wolno ich nigdy separować"9. Propozycja Flucka wydaje się konstrukcją przekonująca, oparta na słusznym - moim zdaniem - założeniu, że kultura stanowi wytwór i zapis ludzkich działań, ale także, zarazem, ma istotny wpływ na reakcje czytelnika. Kultura i czytelnik kształtują się nawzajem.

Pomysł Flucka ma wszakże (przynajmniej) jeden słaby punkt: brak oddzielenia zakresu pojęciowego recepcji od interpretacji. Mimo że zamiarem niemieckiego badacza było poświęcenie wywodu temu pierwszemu zjawisku, w głównej mierze mówi on w zasadzie o interpretacji, czego, jak się wydaje, nie jest do końca świadomy, gdyż utożsamia te pojęcia. Rozgraniczenie recepcji i interpretacji zawsze stanowiło zadanie niełatwe - ze względu na tożsamość części ich zakresów znaczeniowych. Choć trudno wskazać wyraźne rozróżnienie między nimi, warto się tego podjąć. Przedstawię tu kilka stanowisk badawczych dotyczących owej kwestii.

Jedną z propozycji jest pomysł Norberta Groebena, który próbuje oddzielić recepcje od interpretacji, przypisując im odpowiednio skupienie się albo na formie, albo na aspekcie estetycznym tekstu. Według tego uczonego interpretacja to „teoretyczna konstrukcja sensu dzieła na podstawie (odbieranych) znaczeń tekstu i materialno-obiektywnej struktury tekstu", w przeciwieństwie do recepcji, którą autor omawianej koncepcji charakteryzuje bardziej jako odbiór estetyczny ${ }^{10}$. Rozróżnienie to wydaje się jednak nie do końca jasne. Nieco inną, lecz też z gruntu strukturali-

8 Nie oznacza to jednak, że kultura ma moc całkowicie zniewalającą. Celowo nawiązuję w tym miejscu do tytułu przedmowy A. Sza haja (Zniewalajaca moc kultury) do znanego i-wydawałoby się - dobrze już opracowanego polskiego zbioru esejów S. F is h a Interpretacja, retoryka, polityka. Eseje wybrane (Red. A. Szahaj. Wstęp do wyd. pol. R. Rorty. Przedm. A. Szahaj. Przeł. K. Arbiszewski [i in.]. Wyd. 2. Kraków 2008), gdyż w dalszej części artykułu postaram się polemizować z utrwalonymi przekonaniami na temat koncepcji wspólnot interpretacyjnych Fisha. Uważam, że pomysł na odczytanie, które jest zarazem tworzeniem w ramach interpretative communities, niesie więcej wolności jednostce (odbiorcy), niż może się na pierwszy rzut oka wydawać.

$9 \quad$ Fluck, op. cit., s. 383.

10 N. Groeben, Badania nad recepcja jako literaturoznawstwo empiryczne. W zb.: Współczesna 
styczną propozycję przedstawił Gunter Grimm, pisząc, że w gestii interpretacji leży odniesienie do przedmiotu, a także obiektywizm związany ze sprawdzalnością. $\mathrm{W}$ związku z tymi (dość arbitralnie narzuconymi) cechami interpretacją powinien zajać się badacz i profesjonalista. Z kolei do zbioru recepcji literackiej Grimm przyporządkował odniesienie do podmiotu i subiektywizm - dlatego przekonywał, że tym wymiarem powinien zająć się zwykły czytelnik, „normalny konsument”"11.

Trudno stwierdzić, czym Grimm uzasadnia taką dychotomię. Nie wydaje się ona również w najmniejszym stopniu operatywna, pomijając nawet kwestię możliwości łączenia obu opisanych modeli - w przypadku odbiorcy profesjonalnego, ale w danym momencie czytającego subiektywnie i prywatnie (pozostają więc wszystkie odcienie szarości i potencjał gradacji).

Inną próbę odniesienia się to tego zagadnienia podjął Hans Robert Jauss, który dość niejednoznacznie pisał:

Recepcja jako pojęcie estetyczne ma dwa znaczenia, zarazem czynne i bierne; recepcję w sensie estetycznym określa się jako akt o podwójnym charakterze, zawierający w sobie jednocześnie efekt wywołany przez dzieło sztuki i sposób, w jaki jest ono przyjmowane przez publiczność (czy - inaczej mówiąc - jej „odpowiedź”). Publiczność (bądź raczej odbiorca) może reagować bardzo rozmaicie: dzieło sztuki można po prostu poznać, można poddać je krytycznej ocenie, można je podziwiać lub odrzucić, komentować jego treść, przyjąć powszechnie uznaną interpretację lub próbować znaleźć nową. Odbiorca może wreszcie odpowiedzieć na dzieło sam, tworząc nowe dzieło ${ }^{12}$.

Jak zauważa Jauss, zgodnie $\mathrm{z}$ ujęciem historii literatury jako procesu, na który wpływają trzy czynniki: autor, dzieło i czytelnicy, recepcja - w sensie estetycznym - byłaby elementem komunikacji literackiej odbywającej się pomiędzy nimi. Jako składnik zarówno czynny, jak i bierny, jest recepcja w takim akcie jednocześnie przyswajaniem i wymianą. W pierwszym przypadku oznacza to efekt, jaki dzieło wywołuje wśród odbiorców, w drugim zaś sposób, w jaki jest przez nich przyjęte. Na zaistnienie komunikacji pozwalają nieograniczone kompetencje odbiorcy: od zwykłego poznania dzieła, poprzez możliwość krytycznej czy aprobującej oceny, poszukiwania nowej interpretacji, aż do stworzenia dzieła-odpowiedzi.

Kończąc rozważania na temat rozgraniczenia recepcji i interpretacji ${ }^{13}$, chcę odnotować, że bywa również, iż akt komunikacyjny zatacza koło. Dzieje się to w sytuacji, w której autor staje się „odbiorca” poprzez proces pisania. Jak konstatuje Jauss, w wyniku wszystkich tych działań zmienia się - w pewnej mierze - ontologiczny sens dwóch elementów komunikacji: utworu oraz czytelnika. W przypadku tego pierwszego ów nowy sens to, zgodnie ze słowami uczonego, „wynik współwy-

teoria badań literackich za granica. Oprac. H. Markiewi cz. T. 4, cz. 1. Wyd. 2, zmien., popr. Kraków 1996, s. 297 (przel. K. J a c hi m c za k).

11 G. Grimm, Recepcja a interpretacja. W zb.: Wspótczesna teoria badań literackich za granica, s. 267 (przeł. K. J a c h i m c z a k). Zob. cały wywód na ten temat: ibidem, s. 255-267.

12 H. R. J a u s s, Estetyka recepcji i komunikacja literacka. W: Teoria literatury i metodologia badań literackich. Wybór, wstęp D. Uli c ka. Warszawa 1999, s. 267-268 (przeł. B. Pr zybyłow ska).

13 Zob. M. Ry chlew s ki, Interpretacja i konsumpcja. „Przestrzenie Teorii” 2011, nr 15. - M. Ci eśl u k, Sade oczami wspótczesnych Polaków - krytyka literacka, filozofia, kultura masowa. Praca magisterska napisana pod kierunkiem prof. dr hab. M. Skwary. Szczecin 2011, s. 9. Na stronie: http://docplayer.pl/7870386-Sade-oczami-wspolczesnych-polakow-krytyka-literacka-filozofiakultura-masowa.html (data dostępu: 29 I 2019). 
stępowania dwóch czynników: horyzontu oczekiwań (czyli kodu pierwotnego) zawartego w dziele oraz horyzontu doświadczenia (czyli kodu wtórnego), którym uzupełnia dzieło jego odbiorca"14.

Jak stwierdził Jauss, funkcja społeczna komunikacji literackiej może zaistnieć jedynie wtedy, gdy uzna się występowanie relacji o charakterze dialogowym między jej elementami. Pozwala to na rozumienie dzieła literackiego jako specyficznego aktu komunikacji, którego rola nie ogranicza się tylko do przekazania informacji.

$\mathrm{Na}$ recepcję literacką $\mathrm{Z}$ perspektywy komunikacji literackiej patrzy również Głowiński w artykule Komunikacja literacka jako sfera napięć. Spośród kwestii podnoszonych w opracowaniu szczególnie inspirujący wydaje się wątek kompetencji komunikacyjnej, który wiedzie badacza do pojęcia „lektur pisarskich”, określanych przezeń następująco:

Umiejętność [...] stosowania i rozwijania zasad wyprowadzonych z odbieranej wypowiedzi istotna jest dla pewnego tylko typu lektur; można je określić jako lektury pisarskie. Jest to sprawa dla analizy komunikacji literackiej oczywiście bardzo istotna (zwłaszcza gdy chce się analizować rozpowszechnianie się pewnych konwencji literackich, dominację pewnych stylów itp.), stanowi jednak przypadek szczegółowy, a także wtórny, bo pisarskie zastosowanie reguł wyprowadzonych z wypowiedzi będącej przedmiotem recepcji jest zjawiskiem drugiego stopnia; najpierw coś trzeba zrozumieć, by potem móc stosować15.

Utwór i czytelnik nie są jednocześnie wolni od kontekstu kulturowego, który częściowo determinuje recepcję. Nie do końca mogę się zgodzić ze stwierdzeniem, że „najpierw coś trzeba zrozumieć, by potem móc stosować”. Przecież w historii omawianego zagadnienia często zdarzaja się przypadki tak powierzchownych, stygmatyzujących nawiązań do autora-poprzednika, iż trudno mówić w tej sytuacji o jakimkolwiek rozumieniu czy interpretowaniu tekstu ${ }^{16}$. Te przypadki naruszaja cytowaną zasadę. Ciekawe wydaje się, że Głowiński uwzględnia model odbiorcy jako potencjalnego twórcy - to, że odpowiedzią czytelnika może być powstanie tekstu zależnego czy też inspirowanego utworem pierwotnym. Użyte przez badacza określenie „zjawisko drugiego stopnia”, oczywiście, nasuwa na myśl Palimpsesty Gérarda Genette’a i tym samym przywołuje zagadnienie intertekstualności. Właśnie jemu się teraz przyjrzę, odchodząc chwilowo od rozważań nad rolami przypisanymi interpretacji i recepcji.

Wracając - w zasygnalizowanym przed chwilą celu - do zagadnień komunikacji literackiej, warto zauważyć, że w klasycznym schemacie komunikacyjnym Romana Jakobsona (rozwijajacym koncepcję Karla Bühlera) odbiorca-czytelnik widziany jest w zasadzie jako konsument (finalne ogniwo, terminus), bez uwzględnienia jego roli jako twórcy ${ }^{17}$. Gdyby próbować uzupełnić ten model i ujaćc w nim zjawisko lektur pisarskich, trzeba by zapewne porównać go do schematu połączeń sieci neuronowej, w której wszystkie elementy (czytelnicy-twórcy, odbiorcy-autorzy) wchodzą ze sobą w związki, generując swoistą tkaninę intertekstualną. W ramach takiej sieci komunikują się ze sobą na zasadzie rekurencji. W zbiorze recepcji mie-

14 Jaus s, op. cit., s. 268.

15 Głowiński, op. cit., s. 11-12.

16 Pisałam o tym zjawisku m.in. w artykule Proust jako literacki gadżet? Problemy recepcji literackiej.

W zb.: Wymiary powrotu w literaturze. Red. M. G a rb a cik [i in.]. Kraków 2012.

17 R. J a kobs o n, Poetyka w świetle językoznawstwa. „Pamiętnik Literacki” 1960, z. 2. 
ściłaby się zatem intertekstualność, a więc $\mathrm{w}$ ramach odbioru byłaby kategoria podrzędna, jako jego konsekwencja.

Aspekt intertekstualny przenosi ciężar semantyczny dzieła na jego recepcję. Badacze $z$ kręgu estetyki omawianego procesu twierdzą, że znaczenie konstytuuje się w dynamicznym, za każdym razem innym przebiegu lektury, który jest jednocześnie współtworzony przez system konotacji i pamięci, jakimi dysponuje odbiorca. Pamięć i umiejętność reminiscencji pomagają czytelnikowi w identyfikowaniu sensów i odnoszeniu ich do własnych doświadczeń, treści przyswojonych gdzie indziej. Dlatego można powiedzieć, że w utworze intertekstualnym pojęcie recepcji stanowi klucz do jego odczytań. Ze względu na to, iż dzieło nie istnieje inaczej, jak tylko poprzez swoje interpretacje, uwaga badacza dokonującego lektury zostaje skoncentrowana na recepcji tegoż dzieła. Rola, jaką uczony odgrywa w opisanej sytuacji, zaczyna opierać się na kolekcjonowaniu, selekcjonowaniu i porównywaniu powstałych interpretacji literatury. To one stają się elementarnym przedmiotem studiów.

Jednocześnie poetyka recepcji wymusza konieczność podkreślania wszelkich rodzajów uwikłania tekstu literackiego w kulturę, jego „naturę kulturowa”. Jako że teksty funkcjonują w ramach wspólnot interpretacyjnych, każda interpretacja jest uwarunkowana kulturowo. Recepcja stanowi zatem zbiór takich interpretacji, powstałych jako odczytania historyczne (rozłożone w czasie) i jako ślady lektury wspólnot interpretacyjnych, które są nadal i nieustannie realizowane - synchroniczne.

Przechodząc już bezpośrednio do próby odpowiedzi na pytanie zawarte w tytule niniejszego artykułu, warto przypomnieć, że prymat czytelnika (a także autora i tekstu) został zanegowany w ramach - wywodzącego się $z$ kręgu badań neopragmatystycznych - pojęcia wspólnot interpretacyjnych, które stają się gwarantem poprawnego odczytania tekstu (w sposób charakterystyczny dla danej wspólnoty, wobec dyskwalifikacji autora, tekstu i odbiorcy-czytelnika). Według interpretatorów pojęcia wprowadzonego przez Stanleya Fisha:

wspólnota interpretacyjna to pewien sposób patrzenia na świat właściwy danej grupie osób, który sprawia, że osoby te mogą widzieć różne rzeczy mniej więcej tak samo dlatego, iż ten podzielany sposób widzenia świata niejako wy m u s za to $\mathrm{na} \mathrm{nich}$. To znaczy sprawia on, że pewne rzeczy wydają się dla członków danej wspólnoty oczywiste, odpowiednie, rozumne, zrozumiałe, akceptowalne, a inne zdają się niezrozumiałe, nie-do-wytłumaczenia, dziwne, błędne itp. ${ }^{18}$

W syntezach uniwersyteckich dotyczacych recepcji literackiej ten punkt zwrotny (stanowisko Fisha, które wyewoluowało z koncepcji „literatury w czytelniku” do wspólnot interpretacyjnych) bywa uznawany za „upadek estetyki recepcji”, który zamyka „odbiorcę w jego przesądach. Tutaj tekst i czytelnik są zakładnikami wspólnoty interpretacyjnej, do której przynależą, choć może nazywanie ich "zakładnikami" pozostawia im jeszcze zbyt wiele tożsamości" ${ }^{19}$. Compagnon stawia sprawę na ostrzu noża, pisząc:

T. M a r ki e w k a, „Wielki filozof”, czyli spór o interpretację. „Podteksty” 2012, nr 1/2. Na stronie: http://podteksty.amu.edu.pl/content/wielki-filozof-czyli-spor-o-interpretacje.html (data dostępu: 26 V 2013).

19 C o m pa g n o n, op. cit., s. 143. W innym miejscu badacz twierdzi: „nie istnieje już dylemat pomiędzy zwolennikami tekstu i obrońcami czytelnika, skoro oba te pojęcia nie są już postrzegane jako konkurencyjne i względnie niezależne” (ibidem, s. 144). 
wspólnoty interpretacyjne, na modłę repertuaru Isera czy horyzontu oczekiwań Jaussa, to zespoły norm interpretacyjnych, literackich i pozaliterackich, podzielanych przez dana grupę; konwencje, kod, ideologia, jeśli kto woli. Lecz w odróżnieniu od repertuaru i horyzontu oczekiwań wspólnota interpretacyjna nie pozostawia już najmniejszej autonomii czytelnikowi, a dokładniej mówiąc, lekturze, ani tekstowi, który z lektury się wyłania: wraz z pojawieniem się gry pomiędzy odchyleniem i normą zniesiona zostaje wszelka subiektywność ${ }^{20}$.

Dość pesymistyczna wizja „unieważnionego” czytelnika, jaką rysuje Compagnon, opisując wspólnoty interpretacyjne, nie jest odosobniona ${ }^{21}$, ale na szczéście nie pozostaje jedyna perspektywą. Pozytywny wymiar koncepcji Fisha zauważa i podkreśla np. Andrzej Skrendo. Według niego zgodnie z tym ujęciem:

Tekst może mieć kilka znaczeń literalnych (podstawowych) w zależności od punktu odniesienia, przy czym można znaczenia te odróżniać, gdyż są one osadzone w jakimś otoczeniu. Wolno - bez popadania w sprzeczność - obstawać przy wartości swojej lektury, gdyż zmiana odbywa się w ramach kontekstów równoprawnych epistemologicznie ${ }^{22}$.

Skrendo dopuszcza zatem różnorodność wspólnot interpretacyjnych, które poprzez swoją mnogość dają szansę wyboru, a tym samym nie są już tak bardzo opresyjne i ograniczające swobodę interpretacyjną. Celowo zestawiam stanowiska właśnie tych badaczy, aby pokazać, jak odmienna może być recepcja wspólnot interpretacyjnych w ramach różnych wariantów ich samych ${ }^{23}$.

Sądzę, że aby rozstrzygnać, jak Fish definiuje to pojęcie, należy sięgnać do oryginału (nieprzetłumaczonego na język polski) artykułu Interpreting the „Variorum”, w którym zostało ono po raz pierwszy wprowadzone. Wychodzac od interpretacji Variorum Commentary - zbioru studiów dotyczących utworów Johna Miltona - Fish stwierdza:

wspólnoty interpretacyjne złożone są z osób dzielących strategie interpretacyjne dla tworzenia tekstów lub też konstytuowania ich właściwości i przypisywania im intencji. Nie składają się z jednostek dzielących te strategie w celu „odczytywania” tekstów (w zwykłym, „lekturowym” tego słowa znaczeniu). Inaczej mówiąc, istnienie strategii interpretacyjnych poprzedza akt czytelniczy, a nie na odwrót (a contrario do tego, co się zazwyczaj zakłada) - dzięki temu kształtują one to, co jest odczytywane ${ }^{24}$.

Aby zrozumieć pojęcie wspólnot interpretacyjnych, należy odwołać się do zasad logiki prawniczej ${ }^{25}$ i traktować owe wspólnoty jako zbiory. Zgodnie $z$ tymi zasadami zbiór może składać się z jednego bądź większej liczby elementów ${ }^{26}$. W przypad-

Ibidem, s. 144.

Szahaj (op. cit., s. 22) pisze: „przekonania władają nami, a nie my przekonaniami”. Wydaje się, że Fish uznaje te przekonania za coś każdemu człowiekowi wrodzone (element bycia człowiekiem). Skrend o, op. cit., s. 94.

Polski odbiór myśli F i s h a jest mocno uzależniony od polskiego przekładu esejów badacza (op. cit.), który po raz pierwszy ukazał się w 2002 roku.

S. F is h, Interpreting the „Variorum”. „Critical Inquiry” 1976, nr 1.

Pomysł Fisha wydaje się zapożyczony z prawniczych reguł wykładniczych, zasad amerykańskiej jurysprudencji (prawoznawstwa), przeniesionych na grunt literaturoznawstwa. Tworzy ją ciągłość interpretacji jednego tekstu (konstytucji amerykańskiej), której wykładnia zmienia się z czasem nie tylko poprzez system poprawek, ale też poprzez stopniowe modyfikowanie odczytań.

Warto odnotować, że P. Fry (Lecture 24 - The Institutional Construction of Literary Study. Na stronie: http://oyc.yale.edu/english/engl-300/lecture-24 〈data dostępu: 7 XII 2013〉) neguje możliwość istnienia jednoosobowych wspólnot. 
ku wspólnot Fisha elementami zbioru są członkowie wspólnot interpretacyjnych. Mogą oni należeć do jednego lub więcej zbiorów (wspólnot), czyli mogą być częściami wspólnymi kilku zbiorów. Tym, przez co zdeterminowana zostaje przynależność do danego zbioru, jest wykorzystywanie (w odróżnieniu od dysponowania innymi narzędziami - tu właśnie uruchamia się metafora skrzynki narzędziowej) konkretnej strategii interpretacyjnej. Poprzez nie członek wspólnoty „pisze” tekst, czyli określa jego znaczenie. Strategia interpretacyjna zawiera się w tekście, konstytuuje jego właściwości i określa jego cechy.

Członkowie wspólnot nie używają strategii interpretacyjnych do „tradycyjnego” (tzn. pasywnego) odczytywania tekstów. Odczytywanie utożsamia Fish z tworzeniem i pisaniem. Wskazuje, że strategia interpretacyjna musi istnieć przed aktem czytelniczym. Jest to konieczne, gdyż aby coś zrobić, trzeba wcześniej mieć odpowiednie narzędzie. Lecz to narzędzie nie zostaje arbitralnie narzucone, można je nabyć, zmienić, odrzucić, a także samodzielnie wykształcić. Trudno więc mówić tu o zniewoleniu odbiorcy, które przypisuje Fishowi m.in. Compagnon. Amerykański badacz w referowanym tekście właściwie nie podejmuje tematu genezy strategii interpretacyjnych, natomiast porusza kwestie ich przyswojenia. Oznacza to, że nie jest wykluczone samodzielne kreowanie tych strategii. Jak pisze dalej Fish:

Jeśli dogmatem wiary danej społeczności będzie różnorodność tekstów, to tworzący ją członkowie będą dysponować repertuarem strategii do ich wytworzenia [czyli do odczytania interpretującego - A. J.]. Natomiast jeśli inna wspólnota będzie wyznawać istnienie pojedynczego tekstu, wówczas jej członkowie będą zawsze tworzyć przy użyciu pojedynczej strategii. Tak jak pierwsza wspólnota będzie oskarżać tę drugą o redukcyjność, tak ta druga z kolei będzie oskarżać pierwszą o powierzchowność. Wspólnoty te będą wzajemnie przyjmować, że każda odmienna wspólnota błędnie postrzega „prawdziwy tekst”. Natomiast prawdziwym stwierdzeniem stanie się to, iż każda z nich postrzega tekst (bądź teksty) na sposób wymagany przez jej strategie interpretacyjne i na sposób, w jaki te strategie dają tym tekstom życie ${ }^{27}$.

Fish ilustruje opisywaną zasadę działania przykładem dwóch wspólnot. Pierwsza z nich odczytuje tekst w sposób uproszczony, „płaski”, druga zaś - wielowymiarowo, przy użyciu licznych strategii interpretacyjnych. Przykłady te są zestawione w sposób kontrastowy, aby wyraźnie poprzeć argument i pokazać złożoną relację między wspólnotami. Wspólnota (nawet jednoosobowa) dysponująca wyłącznie jedną strategia i korzystająca wyłącznie $z$ niej będzie tworzyć wyłącznie jeden tekst. W przypadku wspólnoty „,wielowymiarowej” konieczne jest użytkowanie wielu tekstów i posługiwanie się wieloma strategiami interpretacyjnymi.

W tym miejscu rysuje się linia sporu między wspólnotami, polegająca na wzajemnych oskarżeniach o błędne/mylne/nieprawidłowe „utworzenie” tekstu (tekstów). Fish nie wskazuje, która ze wspólnot ma „rację”, gdyż stwierdzenie tego pozostaje niemożliwe - żadna ze wspólnot nie nabywa monopolu na ostatecznie prawidłowe odczytanie. Badacz konstatuje na koniec, że nie da się zanegować jedynie, iż każda ze wspólnot postrzega tekst w odmienny sposób, który jest $z$ góry określony przez strategie interpretacyjne zastosowane (wybrane ${ }^{28}$ ) przez nią.

Powyższe wyjaśnia trwałość i jednorodność interpretacji występującej pośród różnych czytelników (gdyż należą oni do tej samej wspólnoty), jak również eksplikuje regularność w tworzeniu różnych te-

28 Wedle tej koncepcji nie ma zdeterminowanego przypisania do określonej wspólnoty. 
kstów poprzez stosowanie różnych strategii przez pojedynczego czytelnika (należącego do różnych wspólnot). Tłumaczy także powody, dla których występują rozbieżności, i to, dlaczego tak często stają się one przedmiotem dyskusji - nie przez niezmienność tekstów, lecz ze względu na to, na ile stabilne są tkanki wspólnot interpretacyjnych i na ile pozwalaja przez to wyrazić odmienności poglądów [ze względu na ustalony skład wspólnoty - A. J.] $]^{29}$.

Podążając za tokiem myślenia Fisha, można dojść do wniosku, że nie istnieje odczytanie kanoniczne, gdyż stałe odczytanie - w konkretnym okresie uznawane za kanoniczne - obowiązuje tak długo, jak długo trwa dana wspólnota interpretacyjna. To czas wystarczający, aby przedstawić jej argument, ale jednocześnie zbyt krótki, aby tym argumentem przeważyć spór (toczony z innymi wspólnotami).

W dalszej części artykułu Fish stwierdza:

Naturalnie stabilność ta nie jest wieczna (odmiennie od tej ponadczasowej stabilności tekstów, do której tęsknilibyśmy). Wspólnoty interpretacyjne mogą się rozrastać i maleć, a ich członkowie mogą się pomiędzy nimi przemieszczać, przez co zaszeregowania nie są stałe, lecz trwałe na tyle, by dalej swoją stabilnością wzmagać toczące się spory interpretacyjne. Jednocześnie wspólnoty interpretacyjne dostatecznie są zmienne, aby uniemożliwić rozstrzygnięcie tych sporów. Tak więc pojęcie wspólnot interpretacyjnych uplasowane jest pomiędzy nieosiagalnym id e ałe m a [...] napędzanym przez wielu strac h e m [przed anarchią interpretacyjną - A. J.] ${ }^{30}$.

Fishowi przypisuje się, że w omawianych przez niego wspólnotach wszystkie strategie interpretacyjne mają ustalony charakter - w ramach konwencji, ideologii i brak miejsca na wolność indywidualnego odczytania. Przytoczony właśnie cytat neguje takie stwierdzenia. Jak wskazuje Fish, wspólnoty interpretacyjne nie sa „zabetonowane” (badacz wielokrotnie podkreśla ich tymczasowość), ich liczebność może ulegać zmianie. Wewnątrz nich występuje fluktuacja tworzących je członków zaszeregowania nie sa permanentne. Oznacza to, że wspólnoty takie nie ograniczają czytelnika w kwestii decyzji co do strategii interpretacyjnej ani też nie dezintegrują go. Wolność odbiorcy polega na dobraniu owej strategii, przez to zaś na rozstrzygnięciu, do której ze wspólnot będzie on należeć. Zatem wspólnoty istnieją między dwoma biegunami - między ideałem niezmiennego znaczenia tekstu a strachem przed anarchią interpretacyjną. Jak wyjaśnia Fish:

I d e ał kompletnej zgody byłby osiagalny jedynie pod warunkiem nieskrępowania tekstów jakąkolwiek interpretacją. Natomiast $\mathrm{strach}$ przed anarchią interpretacyjna ziściłby się w przypadku wystapienia kompletnej dowolności w interpretacjach (tekstotwórczych). Jedynie ta krucha, ale autentyczna, konsolidacja wspólnot interpretacyjnych umożliwia nam rozmawianie, nie dając ani nadziei, ani powodów do obaw, że kiedykolwiek przestaniemy ${ }^{31}$.

Minimalna stabilność (ciągłość) wspólnot pozwala na dialog, który nigdy nie będzie przerwany, gdyż owa stabilność nie jest na tyle silna, aby doprowadzać do kanonizacji danych odczytań.

Innymi słowy, wspólnoty interpretacyjne nie są trwalsze od tekstów, ponieważ strategie interpretacyjne nie są ani naturalne, ani powszechne, lecz wyuczone. Co nie znaczy, że można wyodrębnić punkt, w którym ktoś jeszcze żadnej nie nabył, ponieważ zdolności interpretowania [ability to interpret] nie nabywa się, gdyż jest ona elementem bycia człowiekiem. Nabyć można natomiast sposoby interpre- 
towania [ways of interpreting], jak również można te sposoby zapomnieć bądź wyprzeć, odrzucić na rzecz innych („nikt już nie czyta w ten sposób”). Wraz z tym następuje odpowiednia zmiana w tekstach, ale nie dlatego, że są one inaczej odczytywane, lecz dlatego, że są odmiennie pisane ${ }^{32}$.

W podsumowaniu swojej refleksji na temat wspólnot interpretacyjnych Fish podkreśla wolność czytelnika, który może wybierać różne ich warianty i uczyć się nowych strategii odczytań literatury. Owa wolność w ramach wspólnoty to wyparcie albo rozwinięcie pewnych strategii, a także możliwość stosowania niektórych (lub wszystkich) narzędzi. Strategie interpretacyjne wspólnoty są jednak po-odczytowe, nie zaś oparte na przedsądzie. Zakłada się więc, że nadawanie sensu to tworzenie (odczytywanie to „pisanie”), do którego każdy ma jakąś wrodzoną predyspozycję interpretacyjną. Swoboda w omawianym zakresie wiąże się też z tym, iż każdy odbiorca może wykreować osobną wspólnotę (być pierwszym, inicjującym, lub ostatnim jej członkiem). Pojawia się również paradoks: niewykluczone, że kilka osób będzie czytać identycznie, bo funkcjonuje w ramach jednej wspólnoty, ale także jeden człowiek może przyjmować różne strategie interpretacyjne $\mathrm{z}$ racji przynależności do kilku wspólnot.

Jak stwierdza Skrendo:

Projekt Fisha wydaje się atrakcyjny m.in. dlatego, że stanowi konkurencję dla różnych wersji hermeneutyki. Zamiast wydobywać znaczenie i pytać, co tekst znaczy, trzeba obserwować, jak tekst działa, ponieważ jego znaczenie jest jego działaniem. Być może, tak dałoby się określić to, czym jest dziś recepcja literatury albo po prostu recepcja ${ }^{33}$.

Jak w takim razie rozumieć dziś recepcję? Uważam, iż należałoby powiedzieć, że mamy z nią do czynienia wtedy, gdy nowy tekst zostaje przyjęty do danej wspólnoty interpretacyjnej i staje się swoistym kluczem, wytrychem, strategia interpretacyjną we wspólnocie. Innymi słowy, kiedy czytanie dzieła danego autora (np. Marcela Prousta, snującego refleksje o funkcjach literatury i zadaniach czytelnika oraz o procedurach pamięci) dostarcza narzędzi do pisania i czytania innych tekstów.

\author{
Abstract \\ ANNA JARMUSZKIEWICZ Jagiellonian University, Cracow \\ ORCID: 0000-0001-8810-6456
}

\title{
THE LITERARY RECEPTION: HOW CAN IT BE UNDERSTOOD IN CONTEMPORARY LITERARY STUDIES?
}

The article analyses the problem of contemporary research in literary perception and the possible ways of its development. The analysis is carried out in the context of the perspective offered by the connections between literary reception and literary sociology. Especially much attention is paid to the understanding of interpretive communities-the term coined by an American literary scholar and pragmatist Stanley Fish. The idea of communities underline the readers' freedom due to which they may select different variants and learn new readings of literature. Following this way of reasoning, the article supports the view that the situation in which a new text is adopted by the interpretive community to become a certain key, a picklock, an interpretive strategy, is the essence of literary reception. 